\title{
Auto-antibody testing for children on biologic therapies for rheumatological conditions: results of audit
}

\author{
Julie Duncan*, Jill Heath, Eileen Baildam, Gavin Cleary, Michael Beresford, Liza J McCann \\ From 18th Pediatric Rheumatology European Society (PReS) Congress \\ Bruges, Belgium. 14-18 September 2011
}

\section{Background}

Biologic agents may cause auto-antibody formation and drug induced lupus but no paediatric guidelines exist regarding monitoring of auto-antibodies. The UK Royal College of Nursing Guidance advises checking ANA and anti-dsDNA before starting biologic treatment and repeating anti-dsDNA if concerned.

The Alder Hey protocol tested an autoantibody profile (Table 1, 2) 3-6 monthly for data entry for the British

Table 1

\begin{tabular}{ll}
\hline Diagnosis of patients receiving biologic therapies & $\mathbf{N}^{\mathbf{0}}$ of Patients \\
\hline JA & 102 \\
SLE & 1 \\
JDM & 2 \\
Scleroderma & 2 \\
Uveitis (without arthritis) & 2 \\
Systemic sclerosis & 1 \\
Sarcoid vasculitis & 1 \\
\hline
\end{tabular}

Paediatric and Adolescent Rheumatology (BSPAR) Biologics and New Drugs Registry (BDNR) and children with day ward IV biologic administration often had automatic antibodies testing 4-6 weekly.

\section{Aim}

To analyse frequency of antibody positivity in rheumatology patients on biologics in order to estimate costs and to devise a rational protocol for test frequency.

\section{Method}

A retrospective audit of a 2 year period, August 2008 to July 2010. All patients on biologics were included with data on auto-antibodies collated using the hospital computer system.

\section{Results}

111 children were receiving biologic therapy and 2511 auto-antibodies were tested at a cost of over $£ 26,000$.

Table 2

\begin{tabular}{|c|c|c|c|}
\hline Antibody & $\begin{array}{l}\mathrm{N}^{\circ} \text { of children with positive results / } \mathrm{N}^{\circ} \\
\text { children with antibodies checked [\%] }\end{array}$ & $\begin{array}{l}\mathrm{N}^{\circ} \text { of positive antibodies / } \mathrm{N}^{\circ} \\
\text { antibodies checked [\%] }\end{array}$ & Comments \\
\hline$\overline{A N A}$ & $80 / 111[72 \%]$ & $431 / 540[79 \%]$ & $\begin{array}{l}36 \text { children [32\%] ANA always +ve; } 44 \text { children } \\
\text { ANA sometimes +ve but not always. }\end{array}$ \\
\hline Anti ENA & $4 / 109[<4 \%]$ & $18 / 501[<4 \%]$ & $\begin{array}{l}\text { Always non-specific. Negative on subsequent } \\
\text { testing. }\end{array}$ \\
\hline Anti dsDNA & $1 / 111[<1 \%]$ & $2 / 510[<1 \%]$ & Negative on subsequent testing. \\
\hline ANCA & $14 / 41[34 \%]$ & 25 / 66 [38\%] & Always non-specific (non PR3 / MPO). \\
\hline Anticardiolipin & $6 / 98$ [6\%] & $8 / 894[<1 \%]$ & Negative on subsequent testing. \\
\hline
\end{tabular}




\section{Conclusion}

With the exception of ANA antibody, all other antibody tests were usually negative. Those that were positive tended to be non specific (ie. ANCA non-PR3 / MPO; ENA no specific specificity) and/or were negative on subsequent testing. The results did not alter patient care yet costs are significant. This audit would suggest that antibody tests are checked too frequently at Alder Hey Hospital. A new protocol in development is likely to recommend testing auto-antibodies annually in the absence of clinical signs / symptoms of lupus.

Published: 14 September 2011

doi:10.1186/1546-0096-9-S1-P199

Cite this article as: Duncan et al:: Auto-antibody testing for children on biologic therapies for rheumatological conditions: results of audit. Pediatric Rheumatology 2011 9(Suppl 1):P199.

Submit your next manuscript to BioMed Central and take full advantage of:

- Convenient online submission

- Thorough peer review

- No space constraints or color figure charges

- Immediate publication on acceptance

- Inclusion in PubMed, CAS, Scopus and Google Scholar

- Research which is freely available for redistribution

Submit your manuscript at www.biomedcentral.com/submit
C Biomed Central 